\title{
DOES THE CONCEPT OF LAW NEED OFFICIALS?
}

\author{
Sanne TAEKEMA*
}

Resumen:

El positivismo jurídico moderno puede ser cuestionado por concentrarse excesivamente en el Estado y, en consecuencia, por su incapacidad para explicar el papel del derecho en una sociedad moderna, fragmentaria y globalizada. Un aspecto que no ha sido abordado adecuadamente por esta perspectiva centralizada en el Estado es el papel de los oficiales del derecho. En teorías como las de Jules Coleman y Scott Shapiro la distinción entre los oficiales y los ciudadanos ordinarios ocupa un papel central: en la regla de reconocimiento que fundamenta el concepto de derecho, en el carácter convencional del derecho y en la función del derecho de guiar la conducta. El estudio sostiene que el papel de los oficiales ha sido sobredimensionado y que la distinción entre éstos y los ciudadanos ordinarios ha sido exagerada.

\section{Abstract:}

Modern legal positivism can be criticized for being unduly state-centred, and thus failing to account for the role of law in modern, globalized and fragmented, society. One aspect of that state-centred perspective that has not been addressed adequately, is the role of legal officials. In theories such as that of Jules Coleman or Scott Shapiro, the distinction between officials and ordinary citizens plays a pivotal role: in the rule of recognition that grounds the concept of law, in the conventional character of law and in the guidance function of law. I argue that the role of officials is overstated and the distinction with ordinary people is overdrawn.

* Senior Lecturer/Associate Professor of Jurisprudence, Faculty of Law, Tilburg University, PO Box 90153, 5000 LE Tilburg, The Netherlands. Email: h.s.taekema@uvt.nl; telephone + 3113 4668348, fax + 3113 4668045. I want to thank Govert den Hartogh, Geertje van Schaaijk, Wibren van der Burg and especially Keith Culver and Michael Giudice for suggestions and comments on earlier versions. 
SUMmaRY: I. Introduction. II. Guidance by Legal Rules and Practical Difference. III. Officials and the Practice of Recognition. IV. The Problem of Uncritical Conventionality. V. Broadening the Concept of Law. VI. Bibliography.

\section{INTRODUCTION}

A large portion of the current debate in legal philosophy concerns the character and implications of modern legal positivism. By modern legal positivism I mean legal theories that build on the work of H. L. A. Hart. In this article, I will discuss ideas of legal positivists such as Jules Coleman, Scott Shapiro, and Brian Tamanaha and their contribution to the post-Hart positivist debate about two theses: that the rule of recognition is a conventional practice; ${ }^{1}$ and that legal rules must be capable of making a practical difference. I will argue that both of these central theses build on a common assumption, namely that legal officials are the actors that matter for the concept of law, while ordinary citizens do not. Legal officials matter for two reasons: first, it is the practice of officials that forms the rule of recognition, and second, rules need to guide officials, and merely govern ordinary citizens, in order to be practically relevant. I think this assumption is wrong with regard to both the practical difference thesis and the rule of recognition, for reasons I will advance below. Furthermore, I will indicate the consequences of dropping the assumption in favour of a broader conception of law, which is not as state-centred as the standard legal positivist account. I will also argue why a thin conventional conception of law does not suffice.

Since my argument focuses on the distinction between legal officials and private citizens, it will be helpful to state

1 Two elaborate defences of this thesis are: Coleman, Jules L., The Practice of Principle, Oxford, Great Britain, Oxford University Press 2001, pp. 74-102, and Tamanaha, Brian Z., A General Jurisprudence of Law and Society, Oxford, Great Britain, Oxford University Press, 2001, pp. 133-170. 
specifically my understanding of the group of ordinary citizens. Since I will argue that these non-officials influence the content and scope of law, I want to stress that I take a broad view of this group as actors whose conduct matters legally, including not only individuals, but also organized groups and entities such as companies and nongovernmental organizations.

\section{Guidance by Legal Rules and Practical Difference}

One of the main reasons why legal positivists stress the distinction between officials and ordinary citizens is Hart's claim that it is only necessary for officials to regard legal rules from the internal point of view without ordinary people doing the same. ${ }^{2}$ The upkeep of a legal system depends on the people who are assigned the formal role of applying and enforcing law accepting the rules of their legal system as the appropriate standards. What Hart's idea of the internal point of view means exactly is a matter of debate, ${ }^{3}$ yet there is no need to revisit that discussion here. Instead I will focus on the elaboration of Hart's point by Coleman and Scott Shapiro in terms of law guiding conduct. ${ }^{4}$

Shapiro makes a distinction between norm-governed and norm-guided behaviour. A norm governs behaviour if that behaviour "is subject to the regulation of an actual norm, whether or not the behaviour conforms to the norm". 5 This is contrasted with norm-guided behaviour which "conforms to a norm for the reason that the norm regulates the action

2 Hart, H. L. A., The Concept of Law, 2nd. ed., Oxford, Great Britain, Clarendon Press 1994, pp. 116-117.

3 An influential exchange is that between Perry and Shapiro: Perry, Stephen R., "Holmes versus Hart: The Bad Man in Legal Theory", in: Steven J. Burton (ed.), The Path of the Law and its Influence: The Legacy of Oliver Wendell Holmes, Jr., Cambridge, Great Britain, Cambridge University Press 2000, p. 158-196; Shapiro, Scott J. , "The Bad Man and the Internal Point of View", idem, pp. 197-210.

4 Coleman, Jules, op. cit., n. 1, p. 78 and p. 135 ff; Shapiro, Scott, "On Hart's Way Out", in Coleman, Jules (ed.), Hart's Postscript. Essays on the Postscript to the Concept of Law, Oxford, Great Britain, Oxford University Press, 2001, p. 153 ff.

5 Shapiro, Scott, op. cit., n. 4, p. 153. 
in question". 6 Shapiro uses this distinction for two purposes: first, to argue that it is necessary for officials to be guided by the rule of recognition in order for that rule to govern, and second, to argue that law can only guide conduct if the rule of recognition does not include moral criteria, because only then can law make a practical difference.

That law should make a practical difference is a widely shared view among legal positivists. ${ }^{7}$ The practical difference thesis, however, is problematic. The basic idea is plausible: marking a rule as a legal rule gives people whose conduct is governed by that rule a reason to follow it. However, the further elaboration of that idea is less plausible. A legal rule only makes a practical difference if people follow that rule for the reason that it is law. In other words, their reason must be content-independent: if I pay my taxes because I feel it is only fair to contribute to the upkeep of collective goods such as infrastructure, I am not guided by the legal rule on taxation. If I pay my taxes because the law requires it, I am guided by the legal rule and law therefore makes a practical difference. ${ }^{8}$ Paying for the reason that the law requires it implies that I would not have paid if taxation were not laid down in law. ${ }^{9}$ In the first case, my reasons are content-dependent: I follow the rules because I believe they are worthwhile. ${ }^{10}$

6 Idem.

7 The discussion between exclusive (like Raz and Shapiro) and inclusive positivists (like Coleman) is about the implications of this claim. Exclusive positivists say that an inclusive rule of recognition (including moral criteria) cannot make a practical difference in people's reasoning, while inclusive positivists deny this. See the discussion by Coleman, Jules, op. cit., n. 1, p. 134 ff.

8 Of course, the distinction between content-dependent and content-independent is not as clear-cut as I present it now for the purpose of this argument. A legal rule may inform me of the particular form of a legal duty, while it does not motivate me to perform the basic duty in itself. This distinction between epistemic and motivational guidance will be addressed below.

9 I borrow the taxation example from Sean Coyle ("Practices and the Rule of Recognition”, Law and Philosophy 25, 2006, p. 446) but apply it somewhat differently.

10 I have slightly simplified the argument in order to make the difference between content-dependent and content-independent reasons clear. There is a dif- 
This interpretation of practical difference is quite stringent: the content-independent reason that the legal rule provides must be visible in people's behaviour. Law only makes a practical difference, if people would have acted differently without an appeal to the legal rule. ${ }^{11}$ Such a strict condition is implausible, however. The reason for this is that such a separation between content-dependent and content-independent reasons does not reflect real-life guidance by law: ordinary people have a variety of reasons for following legal rules which are part substantive and part formally-legal. When I decide not to ride my bicycle in a pedestrian area, I do that in part because it is forbidden by law, in part because I accept someone's judgment (who designed the rule) that it is hazardous to allow biking in that area, and in part because I do not wish to inconvenience others who expect me not to ride my bike. The law plays a part in my reasoning, but it is not the whole story. There is a chance that I would not have ridden my bike anyway, even without the legal rule. Moreover, the legal rule plays a role in the different reasons, but not always in the same direct manner. The first reason is content-independent, but the other two are not, even though law plays a role there as well. Accepting the judgment of the law-maker can be seen as obedience to legal authority, but not for a completely content-independent reason: it is because I acknowledge that my own reasoning might be defective on this particular point (I cannot be sure it is safe to ride my bike), so that the legal rule is an added reason for thinking it is hazardous. The third reason is content-dependent: my main wish is to be considerate of others and the legal rule points out how I can, because the legal rule is the basis for their expec-

ference in types of guidance - motivational and epistemic - by law that Shapiro and Coleman rightly make: although my motivation to follow the rule might be content-based, I may still need the rule in order to know what to do exactly. I will address these types of guidance later. Shapiro, Scott, op. cit., n. 4, p. 172.

11 See Shapiro, Scott, ibidem, p. 178: "To know whether a rule makes a practical difference, we must consider what would happen if the agent did not appeal to the rule. The rule makes a difference to one's practical reasoning only if, in the counterfactual circumstance, the agent might not conform to the rule". 
tations. Absent the legal rule, the third reason could still lead to the decision not to ride my bike.

The strict interpretation of practical difference leads legal positivists to the inevitable conclusion that law must only be capable of making a practical difference, and need not actually make a difference, for the simple reason that it is hard to find a legal system where people only follow the legal rules because they are law, i. e. a system where law makes a substantial practical difference. Because the possibility of ordinary people actually being guided by law is so slight, it is natural to limit law's relevance for ordinary people's conduct to legal governance and to limit the guidance claim to officials. So the existence requirement for a legal system is that officials are guided, and not even by the primary rules, but by the secondary rule that determines legal validity.

This makes the positivist position awkward: on the one hand, a basic purpose of having a legal system in the context of Hart's theory is to enable ordinary people to lead their life in a complex society, ${ }^{12}$ while on the other hand it cannot be proven to be of real relevance by actually making a difference. The idea that the proper goal of legal theory is to focus on the strict existence conditions of law, makes positivism too restricted and causes it to lose sight of the equally interesting question: in what way law does figure in ordinary people's lives? If we do pursue that question, a different conception of guidance by law is called for. My claim is that by relaxing the criteria for guidance by law, we have a better description of the role law plays in people's lives. That description does not reduce them to passive or detached subjects of a governing legal system, but takes ordinary people and their reasons seriously.

The most important change needed in the conception of guidance is a reconnection between content-dependent and

12 Having a legal system with secondary rules solves problems of uncertainty, static rules, and inefficiency that a system of merely primary rules has (Hart, H. L. A., op. cit., n. 2, pp. 92-94). 
content-independent reasons. As I have already tried to show in my bike-riding example, even in fairly trivial situations people have mixed reasons for complying with the law. Classic criminal law is the prime example of legal rules that are obeyed not for their own sake, but for moral reasons. Such rules are primarily an affirmation of already existing norms, prohibiting killing or rape. Does this make the fact that they are legal rules irrelevant from the point of view of the rule-followers? Not at all: many people expect their legal system to reflect the basic values of their society, and prohibition by law indicates the importance of the rule.

Moral reasons are one variety of content-dependent reasons, but there are other such reasons that are primarily practical. Large portions of private law are simply useful to people: they enable people to do business and arrange their lives efficiently. People do not care for the specific content of these rules; they mainly serve to take work off their hands. Does this mean these rules are followed for content-independent reasons then? No, that does not follow: the reasons behind those rules, their rationale, are important. We might describe the content-related reasons in play here as second-order reasons: the specific content of the rule is not the reason for compliance, but the reason for having such a rule is. ${ }^{13}$ Rules solving coordination problems are the traditional example. People follow such rules not only because they are law, but also because they serve to coordinate their behaviour with that of other people.

Shapiro and Coleman may claim that they can accommodate such practical reasons because they distinguish between motivational and epistemic guidance. In Shapiro's words: "The rule can motivate action simply in virtue of the fact that the rule regulates the action in question. Or it can inform the person of the existence of certain demands made

13 Joseph Raz makes the distinction between operative reasons and auxiliary reasons (Practical Reason and Norms, London, Great Britain, Hutchinson of London, 1975 , pp. 33-35): in my example, the content-related reasons are operative reasons, while coordinating rules are auxiliary. 
by those in authority and, as a result, that conformity is advisable". ${ }^{14}$ They would also say that coordinating rules guide epistemically: they pick out the rule for people, so that people know what to do. Epistemic guidance is primarily seen as, first, communication between officials and ordinary people, and second, as officially designated rules that supply normative choices for citizens. Motivational guidance involves a belief in the legitimacy of the legal rule; only motivational guidance is the taking of an internal point of view towards legal rules. ${ }^{15}$ If someone is motivated to conform merely by the threat of punishment, the rule specifying which conduct will be punished guides epistemically only. This leads Shapiro and Coleman to modify the conclusion that only officials need to be guided by law to the claim that only officials need to be motivationally guided by law, while ordinary people need to be epistemically guided only.

Although this is an improvement on the original positivist claim, it is still problematic for two reasons. The first problem is Shapiro's characterization of epistemic guidance as mediation between officials and non-officials. ${ }^{16}$ The second problem is the separation between officials as motivationally guided and ordinary people as epistemically guided. The first problem arises from Shapiro's explanation of the epistemic guidance function of legal norms as those norms mediate between officials and non-officials in the sense that "they eliminate the need for officials to issue particularized orders". ${ }^{17}$ This interpretation of epistemic guidance is based on the idea that law is an instrument used by officials. This idea is haunted by Austin's command model of law: officials want non-officials' behaviour to conform to their wishes, with the addition of rules in between to make the commands of the officials more efficient. They do not need to tell every single citizen separately what their duty is, offi-

14 Shapiro, Scott, op. cit., n. 4, p. 172.

15 Ibidem, p. 174.

16 Idem.

17 Idem. 
cials make a rule that tells citizens what their duty is. However, the main idea is still that authoritative figures want to give orders to subjects. To appreciate the influence of the command model on Shapiro's argument, it is useful to contrast command and custom models of law. The custom model sees rules as emanating from patterns of interaction between people: the legal rules arise from the moral and social norms that people adhere to. Rules of sale at farmers' markets are rules based on their practices, not on an external authoritative order.

Hart's theory is distinctive in part because it works from both models: he criticizes and modifies Austin's command theory (introducing the internal point of view) and he points out the weaknesses of the customary model (introducing secondary rules). In the customary model, official law is needed if there is uncertainty or conflict about which rule is to be followed (Shapiro's second epistemic role of law: making normative choices). This is not fruitfully seen as a command, but more naturally as official endorsement of an existing rule. Such rules do not mediate between officials and non-officials, they facilitate action by people.

So the idea of epistemic guidance makes sense in the second sense, as "[eliminating] the need for non-officials to solve every normative problem by themselves". ${ }^{18}$ This is a key element in many theories of law, including for instance, the natural law theory of John Finnis: ${ }^{19}$ law serves to choose a solution when there is more than one good answer to a problem. In such a situation, where it is not directly clear what is the right thing to do, or when there is the possibility of disagreement about it, a legal solution is useful. However, it is not obvious why officials need to be the ones providing the solution (or have less of a need for epistemic guidance than ordinary people). An officially determined rule solves the problem, but there are other solutions that

18 Ibidem, p. 173.

19 Finnis, John, Natural Law and Natural Rights, Oxford, Great Britain, Clarendon, 1980, p. 276. 
need not bear the stamp of official law. Consider a normative problem: should children be exposed to television commercials for alcohol? This normative problem of balancing the freedom to advertise against the health of children can be given the solution of a state legal rule forbidding alcohol commercials before nine in the evening. ${ }^{20}$ It can also be solved by the alcohol industry agreeing among themselves to restrict their commercials. Once they have taken that decision, each individual producer no longer needs to think about a personal or corporate policy in each case. For this particular kind of problem, i. e., coordination by one solution to solve normative problems, unofficial rules, such as self-adopted rules, may serve just as well. Epistemic guidance does not need official law.

A second problem remains for the positivist view, however: the gap between guidance for officials and non-officials, restricting to officials the requirement of motivational guidance. Again the inheritance of Austinian theory makes itself felt: modern legal positivism has improved on Austin by introducing the internal point of view, but it is still committed to Austin's idea that a legal system that only governs unwilling subjects should fall within the range permitted by the concept of law. Epistemic guidance is compatible with the figure of the "bad man", the person without a conscience whose only motive for complying with legal rules is narrow self-interest. Even a system governing a whole society of bad men can be a legal system as long as the officials are bona fide. Motivational guidance by law is something special that is not often apparent in the behaviour of ordinary people. In the legal positivist picture, motivational guidance by law is actually undermined from two directions: the bad man and the moral man. The bad man is reluctant to comply, the moral man does not need law to urge

20 This particular legal prohibition is a government proposal in the Netherlands, part of the coalition agreement containing the policy goals of the government formed in 2007 (Coalition agreement of 7 February 2007, http://www.reger ing.nl/Het_kabinet/Regeerakkoord, p. 40). 
him to comply. ${ }^{21}$ That modern legal systems aim at having content that is in accordance with what the majority of people believe in, becomes irrelevant for the concept of law.

The use of the extremes of the bad and the moral man focusses our attention on a problem that is too specific: instead of trying to understand how law figures in ordinary people's motivation for action, we are led to consider its role for people who could care less, for whom law is uninteresting or at best annoying. The puzzle is: how can we explain that most ordinary people generally comply with law, without assuming they have a particular moral character? Legal positivists want to address that puzzle, but they approach it from the wrong angle.

Instead of asking what makes law capable of guiding conduct, we should ask in what way law can motivate people. If we consider the reasons for following a legal rule, it is clear that law figures in reasoning in different ways. This indeed ranges from the avoidance of the bad consequences threatened by law (the bad man perspective), such as sanctions, to the acceptance of the legal norm because it is morally right (the moral man perspective). My claim would be that law figures in people's actions largely in a positive way, because it is useful to them, and that law loses its point if it fails to contribute positively. I would like to call this broader, less extreme view, "the practical man perspective".

What does it mean to be positively motivated in action by law? It means that someone sees the usefulness of the legal system in general, and of particular legal rules, for his own actions in the context of interactions with others. I deliberately employ the term 'usefulness' here, because it refers to the thought of classical pragmatism, in which law is one of the practices that serve to solve problems. Law, from this theoretical perspective, is primarily facilitating activities: it

21 For the moral man, law does not make a practical difference, because the moral man is motivated to do the right thing anyway. 
helps to plan, execute and coordinate actions. ${ }^{22}$ What makes law useful is, first of all, its content: the specific substance of legal rules and principles makes it possible to attach consequences to behaviour. Rules of adoption, for instance, establish formal ties between a parent and child, giving the child the right to support by the parent and the parent the possibility to decide about the child's upbringing, etc. People are motivated to follow those rules of which they can understand the importance for their lives and actions. That motivation based on content can have a moral character, a self-interested character or a practical character, with practical motivation meaning: valuing that legal rules serve purposes such as efficiency and security. I may also be morally indifferent about a particular rule, while acknowledging that it makes certain social interactions more efficient, a goal that I may value highly.

Although it is easier to argue why particular legal rules facilitate action, there is also a general argument for seeing the legal system as a whole in such a role. Given the complexity of modern society and the ensuing multitude of possible interactions with others, having general rules to govern these interactions is necessary. ${ }^{23}$ Recognizing that overarching role of the legal system can also be a motivation to follow legal rules. From a legal positivist perspective, that would be a motivation based on content-independent reasons: we need legal authority to make normative choices regardless of content. From a pragmatist perspective, the characterization of this motivation need not be so strictly categorized as either content-dependent or content-independent. Such a system-level argument is still connected to

22 Dewey, John, "My Philosophy of Law", in My Philosophy of Law: Credos of Sixteen American Scholars, Boston, Massachusetts, USA, Boston Law Book Co., 1941, p. 77, compare Taekema, Sanne, "Beyond Common Sense: Philosophical Pragmatism's Relevance to Law”, Retfaerd - Nordisk Juridisk tidsskrift 29/nr. 4, 2006, p. 27.

23 This is inspired by Lon L. Fuller, e.g. in his essay "Human Interaction and the Law" in Fuller, Lon L., The Principles of Social Order: Selected Essays, edited by Ken I. Winston, Durham, North Carolina, USA, Duke University Press, 1981, pp. 111-146. 
substantive reasons, although these are second-order reasons: the justification of those rules is then indirect, unlike the justification for particular rules which is directly based on their content. Although this may seem a terminological move - I call content-related what is content-independent for legal positivists - there are important consequences. By seeing the reasons for obeying legal rules as content-related, albeit in a range of different ways, the question of why rules should be followed remains connected to the discussion. What I mean is that this perspective can make sense of people who follow the law generally, but transgress certain specific rules. Although someone may obey the rules that forbid smoking on trains, that same person may disobey the rule for not smoking on open-air platforms, because the point of the inside ban on smoking is seen as legitimate while the outside ban is not. Such selective following of rules is not particularly problematic as long as the legal system as a whole is perceived as legitimate by the majority of its subjects.

This approach means that a particular point of view is indeed privileged over others, a practical internal point of view in which law is seen as obligation-imposing. These obligations, however, cannot be overriding in all circumstances: because not all purposes that law serves are moral, legal obligations can conflict with moral obligations. ${ }^{24}$ In case of such conflicts, it is the responsibility of the individual to find a solution. One way in which this may be done is by actively trying to change the particular legal rules that cause the conflict. 25 When individual citizens take up that responsibility they take part in the practice of shaping the law, an active role that also has implications for the concept of law. I now turn to the role of ordinary

24 This refers to the familiar discussion about the moral obligation to obey the law that falls outside the scope of this article. I refer to it here to introduce one type of response to a conflict of obligations.

25 Civil disobedience (as described by Rawls, John, A Theory of Justice, Cambridge, Massachusetts, USA, Harvard University Press, 1971, p. 319) is a classic form of such an effort to change the law. 
people with regard to the concept of law, more specifically to their role for the rule of recognition.

\section{Officials AND the Practice of Recognition}

In his discussion of the character of the rule of recognition, Coleman briefly addresses the argument that his idea of the rule of recognition as a practice of officials is flawed because officials themselves are instituted by law. The objection is that his account is circular: officials determine what the rule of recognition is, while the rule of recognition determines who counts as an official. His answer to the objection, however, is not convincing. It is worth quoting at length:

We must differentiate between two distinct roles that the same group of individuals plays in the conventionalist story. First, some group of individuals -we do not call them officials and we need not identify them by reference to lawschoose to have their behavior guided by a certain rule. In other words, they take the rule as giving them good reasons for action. If that rule takes hold in the sense of establishing membership criteria in a system of rules, and if those rules are complied with generally, and if institutions of certain types are then created, and so on it is fair to say that a legal system exists. If a legal system exists, then that rule which guides the behavior of our initial group of individuals is correctly described as the rule of recognition for that legal system. And those individuals who guide their behavior by that rule are thus appropriately conceived of as "officials". They are, in a sense, officials in virtue of that rule, but they are not officials prior to it (in either the factual or the logical sense). ${ }^{26}$

There is one element conspicuously lacking in this answer: why does a random group of individuals suddenly choose to guide their behaviour by a rule (of recognition)? 
What marks out this particular group as the ones who should concern themselves with the use of a rule that determines whether other rules are law? An account of officialdom must at least have a story about the selection of the group. In order to avoid circularity that story cannot depend on formal establishment of the officials by law.

In what follows, I will first address the argument that officials are those with recognized authority. Secondly, I will discuss the argument that officials need to practice the rule of recognition in the course of their other tasks. Thirdly, I will counter the argument that only the interpretation by officials of the rule of recognition matters. I hope to show that all three arguments cannot be sustained and that the practice of recognition is as much a matter of ordinary people as it is of officials.

Regarding the primary establishment of officials I see two possibilities: first, the group may distinguish itself by means of power, that is, they may be in a social position to claim that they are the ones who should decide what is law and be able to enforce their position. This possibility, however, does not fit the overall idea that law is a legitimate force, in Hart's words, not a 'gunman situation writ large'. ${ }^{27}$ We need an account of legal officials that is not simply reduced to the naked fact of who is in charge, but makes them part of a legitimate system.

The second possibility is that officials are recognized as such by others. The group of individuals does not appoint itself as officials, but the larger group for whom the legal rules are meant recognizes the smaller group as the ones who should practice the rule of recognition. The small group of "officials" depends on the ordinary citizens to perceive them as having the authority to determine what the law is. This second possibility is more interesting because it involves a relationship of authority instead of a relationship

27 Hart, H. L. A., "Positivism and the Separation of Law and Morals", in Dworkin, Ronald (ed.), The Philosophy of Law, Oxford, Great Britain, Oxford University Press, 1977, p. 19. 
of mere coercive power. It also raises the question why they are recognized as officials with authority. A fruitful way of approaching this question is to ask what reasons ordinary people have for not practicing the rule of recognition themselves but recognizing a special group as authorized to practice it.

One reason is that ordinary citizens may find it difficult to determine what is valid law by themselves and therefore choose to have an expert or wise person perform this task for them. The authority of the persons applying the rule of recognition in that case derives from their expertise. ${ }^{28}$ It makes more sense to ask someone who already knows something of law, rather than an arbitrarily chosen person, to determine what is valid law, even though this situation might also involve a simple division of labour (if you figure out what the law is, I will put food on the table). This idea of having officials to perform burdensome tasks is premised in part on the idea that ordinary citizens do not want to do it themselves. However, framing the issue this way makes clear that such a division of labour is by no means necessary. In a society modelled like the Athenian polis it is not strange to think of the assembly of free citizens not only making the legal rules, but also resolving conflicts according to these rules and determining which rules are valid law. Such radical democracy shows that officials are not a necessary feature: it is possible to have a system with secondary rules practiced by citizens themselves.

However, in complex modern societies, there are practical barriers to radically democratic decision-making within a legal system. ${ }^{29}$ If we grant that under the conditions of

28 Traditionally, a distinction is made between theoretical authority (based on expertise, for example, the authority of a doctor) and practical authority (based on decision power, for example, the authority of a legal official). That law should be regarded as a practical authority is disputed by, e. g. Heidi Hurd (Moral Combat, Cambridge, Great Britain, Cambridge University Press, 2004).

29 Although there is a wide range of systems from the more democratic to the less democratic: the referendum and the lay jury in courts are examples that show that the democratic element can have a more important place. My thanks to Wibren van der Burg for pointing this out. 
modern life it is extremely rare to see a legal system without officials practicing a rule of recognition, it is worth exploring what these officials are expected to do. Put simply, they are expected to determine and make clear what the law requires. In the traditional legal positivist picture, the officials who practice the rule of recognition are usually judges. ${ }^{30}$ Judges have the task of determining whether particular rules are valid law. Why judges? This brings me to the second main argument: that practicing the rule of recognition is a task that accompanies other tasks officials have.

This argument often remains implicit, but the most obvious reason for judges to be concerned with the rule of recognition is that judges need to determine what valid law is in order to perform their other main task well. If they are to do a good job of resolving disputes according to law, they need to determine what the law relevant to the case is exactly. Although it is conceivable that there is a legal system in which these two tasks are always performed by separate bodies, it is practical to combine them. Questions regarding the validity of a particular rule do not appear of the blue, they arise out of uncertainties over the specific legal duties citizens have. Because legal validity of the relevant rules is a prerequisite for assuming legal obligations, it is quite difficult in practice to separate the activities of recognizing valid law and determining the extent of legal duties in disputes. Recognition of judges as officials who legitimately determine what law is, thus occurs in the context of their broader role of legal interpretation and dispute settlement.

So far, I have only shown why officials, understood most typically as judges, are recognized as the legitimate practitioners of the rule of recognition: because they need to do so to perform their task of dispute resolution well. This argument is based on the assumption that judges are indeed the ones who practice the rule of recognition. But is that a fair picture of what the practice of recognizing law involves?

30 Coleman, Jules, op. cit., n. 1, p. 96. 
Imagine two company managers drafting a contract. They consult the law books and maybe call a lawyer to establish whether their contract is roughly in accordance with the rules of private law. However, they put in one clause that to the letter violates the law of their jurisdiction. Let us assume that this clause is not unfair and that the two apply it without trouble until one of the companies undergoes a change of management, and the new manager challenges the clause in court. It might happen that a judge then decides that, although the clause was against the letter of the law, it is fair and under the circumstances should remain valid. In such a case, is it fair to say that it is only the judge, the official, who practices the rule of recognition? The two contract drafters also thought about the validity of the legal rules and even reinterpreted it in the light of fairness. Or should we say that they also to some extent practiced the rule of recognition?

Here we come to the third argument of the positivist view. Seeing officials as the exclusive determiners of what is valid law, makes the final determination of validity the only relevant moment. Only the activity of the officials who make the ultimate decision on how the rule of recognition is to be applied, is to be regarded as relevant for the practice of recognition. This seems wrong for two reasons. First, the familiar problem regarding customary law resurfaces: is it necessary for a customary rule to be explicitly recognized as valid law by an official for it to count as law? If that were the case, rules that are never tested, that are never subject to an official decision on their validity would not be law, which is a strange conclusion. If the rule of recognition contains the norm that certain customs are considered law, these customs are law in virtue of that norm, not in virtue of the explicit application of that norm. Therefore, it seems that the practice of recognizing valid law is broader: it is not only the group of officials that apply the norms of the rule of recognition but ordinary citizens do so as well. The key to the practice of recognition is the use of legal rules: by inter- 
preting legal rules so that they are relevant to conduct, those who use the rule are involved in determining its validity.

Working from a model that puts officials at the centre of the practice of recognition, as legal positivists do, this may seem strange. Is it not the point of a rule of recognition to determine what valid law is for the users of legal rules? The positivist view assumes that only the final, definitive, determination counts as practicing the rule of recognition. The second reason for doubting the view is that, if we make that assumption, even lower court judges do not practice the rule of recognition. The determination of validity made by lower court judges is not final either, as it is always in principle subject to overruling by the highest court. (By the way, this shows how important acceptance of the judgment of validity by the citizens involved is: if they do not challenge that judgment, it is final). The users of legal rules, however, only need determination by legal officials, if they are incapable of determining legal validity themselves; often it is perfectly clear to them what the valid legal rules are, so that the activity of an official is unnecessary. If validity is a problem, then it is a problem put forward by the users of legal rules for official solution. And in that case, we should not underestimate the influence of arguments put forward by citizens (and their lawyers) on the determinations of the official judge. Therefore, it makes more sense to see the practice of recognition as one shared by officials and ordinary citizens.

\section{The Problem of Uncritical Conventionality}

My arguments so far have shown that both the rule of recognition and the guidance function of law should incorporate the perspective of ordinary citizens. A similar argument is made from a socio-legal perspective by Brian Tamanaha, who proposes a new concept of law: "Law is whatever people identify and treat through their social 
practices as "law"”. ${ }^{31}$ In Tamanaha's theory, the conventions of ordinary citizens determine what is law and who is a legal official, ${ }^{32}$ thus broadening the concept of law to include state law, customary law, indigenous law, international law and natural law, all of which count as law as long as they are treated as such. ${ }^{33}$ Tamanaha's point of departure, like Coleman's or Shapiro's, is the theory of Hart, but he strips that theory of all functional and essentialist elements to retain only its conventionalism. This radicalization of the conventionalist element in legal positivism definitely answers my criticism that ordinary citizens are neglected, because their point of view is made central. This kind of theory nonetheless contains problems of its own regarding the work a concept and a theory of law are supposed to do.

The most striking feature of Tamanaha's concept is that it is completely unconstrained: it accepts anything as law as long as people treat it as law, if it carries the label "law". This follows from Tamanaha's rejection of necessary features of the concept of law and from his rejection of law performing specific functions. Thus, the theorist's role in concept formation is severely reduced: what law is, is a completely empirical question. This reduction of the role of theory I believe to be mistaken. My main reason is that a thicker concept of law can help address questions of the proper role of law in society and in people's lives more fruitfully than a thin conventional concept can. Such a thicker concept needs essential and functional elements. Here the distinction between a weak definition and a strong concept, made by Selznick, is helpful to underline my point. A definition should be weak in order to serve as a heuristic device, i.e. to catch phenomena that are relevant objects of re-

31 Tamanaha, Brian, op. cit., n. 1, p. 166.

32 "A "legal" official is whomever, as a matter of social practice, members of the group (including legal officials themselves) identify and treat as "legal» officials". Ibidem, p. 142.

33 Ibidem, p. 225. 
search; a concept should be strong in order to give a judgment on what should or should not count as law. ${ }^{34}$ In Tamanaha's approach, the concept of law is reduced to a definition, and while I have no fundamental objection to his approach as a weak definition, that approach is much too thin to provide a concept of law up to the explanatory jobs of a concept of law.

With Tamanaha's definition as concept, we can imagine, e. g., the laws of physics being law. These are called law and it is possible for a group of people to treat them as law. What it means to treat something as law in Tamanaha's view, remains unclear; for instance, his definition does not include following rules or regarding rules as normative as part of the meaning of law. It is reducible to the label: if people refer to it as law, it is law. ${ }^{35} \mathrm{We}$ can imagine the group who regard the laws of physics as law as also having moral and social rules that prescribe and prohibit certain conduct, provide procedures for resolving conflicts, etcetera. If this group denies that anything other than the laws of physics are law, Tamanaha would have to accept this view of law as legitimate. His theory does not provide any substance to enable criticism of particular conceptions of law. In my example, the social rules that have the roles usually performed by law have dimensions in common with law that the laws of physics lack, but without an account of the elements necessary for law, there is no meaningful way of comparing these social rules to legal rules.

It is clear why Tamanaha thinks ascribing inherent features or functions to law is problematic: in many societies, what is officially called law is completely dysfunctional.

34 Selznick made this distinction for purposes of socio-legal research, in the context of legal theory it entails that concepts need to be underpinned by theoretical arguments why something should or should not count as law in its full sense (Selznick, Philip with P. Nonet and H.M. Vollmer, Law, Society, and Industrial Justice, New York, USA, Russell Sage, 1969 p. 4).

35 This criticism was already formulated by Twining in his review of Tamanaha's book: Twining, William, "A Post-Westphalian Conception of Law", Law and Society Review 37, 2003, pp. 199-257. 
Tamahana particularly thinks of colonial legal systems in which French or American law were the official legal systems, but in which the indigenous population used different rules to perform legal functions such as the resolution of conflicts or the punishment of deviant behaviour. ${ }^{36}$ What he wants to avoid is the conclusion that, because the official law in a particular society does not do anything that law is supposed to do, its official law is not really law. However, Tamanaha's criticism only holds against the claim that law does in effect fulfil the function of providing order (or some other function): if you claim that law actually performs such a function, the existence of non-functioning systems is a problem. His criticism does not invalidate the claim that law aims at providing a particular function, but may in practice fail to do so. As William Twining points out, function is an ambiguous term that can refer both to purpose and to effect, or to the combination of both. ${ }^{37} \mathrm{~A}$ functional element can be included in a thicker concept of law than Tamanaha's without being vulnerable to his criticism, as long as it is taken to refer to the purposes of law as the necessary element at the conceptual level. Function in terms of actually realized effect is not a necessary element of the concept of law but a contingent feature of a given legal system. The main reason for including a functional element in the concept of law is critical: legal systems claim to fulfil practical purposes as their justification, while many systems fail to do a good job. A meaningful theory of law needs to be able to evaluate the functional quality of legal systems. ${ }^{38}$ Tamanaha does not pay enough attention to this critical role of a concept of law. ${ }^{39}$

36 See Tamanaha, Brian, op. cit., n. 1, pp. 145-146.

37 Twining, William, op. cit., n. 33, pp. 213-214.

38 This is the way functionalism figured in American Legal Realism: as a critical claim, see De Been, Wouter, Legal Realism Regained: Saving Realism from Critical Acclaim, Stanford, California, USA, Stanford University Press 2008, p. 89.

39 This criticism of Tamanaha is perhaps somewhat unfair, since his proposed socio-legal concept of law may be useful for empirical social science. Still, it is a 
Tamanaha's commitment to socio-legal positivism leads him to neglect an important feature of law in the life of ordinary people: its normativity. That law purports to govern behaviour through the use of rules and principles is such a central characteristic of the concept of law that expanding the definition of law beyond that makes the concept of law completely empty. However, even if law's inherent normativity is accepted, an important issue remains: what distinguishes law's normativity from the normativity of other social practices? 40 Merely saying that law aims to fulfil important functions in society by attempting to govern behaviour by rules and principles, is not enough to distinguish law from morality or other social practices. At this point, there are a number of options. Most of the authors previously discussed defend variants of Hart's theory of a system of primary and secondary rules administered by legal officials. However, in order to avoid the problems I have identified concerning officials, I will focus on the specific normativity of law.

\section{BROAdENING THE CONCEPT OF LAW}

In order to construct a conception of law that does not privilege the position of officials, I propose to start with law's guidance capacity for citizens. As I argued above, it is possible to see legal rules as guiding ordinary citizens both epistemically and motivationally without disconnecting the legal character of rules from their content. Once the distinction between citizens and officials with regard to guidance by law is no longer relevant because both can be guided motivationally, it becomes possible to extend other elements of what positivists see as the domain of officials as well. Most importantly, the idea of rules being constituted in practices can be broadened beyond the rule of recogni- 
tion being practiced by officials. If it makes sense to see the validity of rules as determined in practice, it is also conceivable that legal rules in general are practice-based. What a practice-based view of legal rules amounts to, depends on one's view of practices.

In Hart's, and Tamanaha's, theory practice-based rules are conventional: he understands practice-based rules as social rules that are followed because others follow them as well. ${ }^{41}$ However, the categorical difference between social and moral rules - as convention-based versus convictionbased - does not translate to law. Hart rightly states that law cannot be understood as consisting completely of social rules, but I disagree with his view of practice-based rules as conventional social rules. A practice-based view of law is not necessarily merely conventional. In contrast to Hart's view, practices can be described as having a normative point, which has independent normative force. ${ }^{42}$ It is then the content of that normative point that determines the specific character of the practice. With such a view of practices in mind, law also needs to be identified as a practice with a specific normative point. As I have argued elsewhere, what distinguishes law from other practices is its orientation towards a set of specifically legal values. ${ }^{43}$ Seeing law as a normative practice that not only incorporates rules and principles, but that is oriented towards a set of specifically legal values, makes it possible to distinguish law from other social practices without needing to claim that law's practical relevance is dependent on content-independent reasons. Law's content has a different focus than morality or economic practices, because it is oriented towards ideals

41 In his reply to Dworkin in the Postscript, Hart clarified his earlier account of social rules: "Rules are conventional social practices if the general conformity of a group to them is part of the reasons which its individual members have for acceptance" (Hart, H. L. A., op. cit. n. 2, p. 255).

42 See MacIntyre, Alasdaire, After Virtue: A Study in Moral Theory, Notre Dame, Indiana, USA, University of Notre Dame Press, 1984, pp. 187-196.

43 Taekema, Sanne, The Concept of Ideals in Legal Theory, The Hague, The Netherlands, Kluwer Law International, 2003, p. $171 \mathrm{ff}$. 
of legality, justice and legal certainty. These ideals make the procedural and rule-based character of law important, but law is not reducible to that procedural practice.

In the context of the present discussion about officials, this argument about law as a value-oriented practice can be extended to include an argument about the actors involved in the practice of law. A view of law as a value-oriented practice need not make any assumptions about who is the main actor in that practice: in principle, all those involved in making, developing and applying rules as ways of realizing legal values are practitioners of law. This does not mean, of course, that everyone is equally involved as a matter of practice, but it does mean that conceptually there is no privileged group. Different actors contribute to the practice of changing rules, for instance, in various ways which cannot be neatly categorized as the exclusive province of one group. Even in the one of the clearest cases of a group of officials with a specific role, that of judges, there is the creative input of citizens and lawyers before the judicial decision and the recognition of the decision afterwards that are integral parts of the practice of changing the rule.

Such a view of law can more easily acknowledge new (or old, for that matter) forms of law that do not involve state officials as the central actors: e.g. private regulation by commercial branch organizations, international agreements between companies, states and non-governmental organizations, or alternative dispute resolution. Insofar as such phenomena are aimed at legal values and make use of legal mechanisms, they should be recognized as law in a practice-based view. The authority of officials is not the only legal solution to problems of regulation. If the content of these alternative solutions is oriented towards legal values, and if people are motivated to follow them because of the goals they serve there is good reason to include them in the concept of law. 
VI. BIBLIOGRAPHY

Coleman, Jules L., The Practice of Principle, Oxford, Great Britain, Oxford University Press, 2001.

COYLE, Sean, "Practices and the Rule of Recognition", Law and Philosophy 25, 2006.

DE BeEn, Wouter, Legal Realism Regained: Saving Realism from Critical Acclaim, Stanford, California, USA, Stanford University Press, 2008.

DEWEY, John, "My Philosophy of Law", My Philosophy of Law: Credos of Sixteen American Scholars, Boston, Massachusetts, USA, Boston Law Book Co., 1941.

FINNIS, John, Natural Law and Natural Rights, Oxford, Great Britain, Clarendon, 1980.

FUller, Lon L., The Principles of Social Order: Selected Essays, edited by Ken I. Winston, Durham, North Carolina, USA, Duke University Press, 1981.

HART, H. L. A., "Positivism and the Separation of Law and Morals”, in DwORKIn, Ronald (ed.), The Philosophy of Law, Oxford, Great Britain, Oxford University Press, 1977.

Clarendon Press, 1994.

HuRD, Heidi, Moral Combat, Cambridge, Great Britain, Cambridge University Press, 2004.

MACINTYRE, Alasdaire, After Virtue: A Study in Moral Theory, Notre Dame, Indiana, USA, University of Notre Dame Press 1984.

PERRY, Stephen R., "Holmes versus Hart: The Bad Man in Legal Theory", in BuRTON, Steven J. (ed.), The Path of the Law and its Influence: The Legacy of Oliver Wendell Holmes, Jr., Cambridge, Great Britain, Cambridge University Press, 2000. 
RAWLS, John, A Theory of Justice, Cambridge, Massachusetts, USA, Harvard University Press, 1971.

RAZ, Joseph, Practical Reason and Norms, London, Great Britain, Hutchinson of London, 1975.

SELZNICK, Philip with P. Nonet and H.M. Vollmer, Law, Society, and Industrial Justice, New York, USA, Russell Sage, 1969.

SHAPIRO, Scott J., "The Bad Man and the Internal Point of View", in BurTon, Steven J. (ed.), The Path of the Law and its Influence: The Legacy of Oliver Wendell Holmes, Jr., Cambridge, Great Britain, Cambridge University Press, 2000.

—_, "On Hart's Way Out", in Coleman, Jules (ed.), Hart's Postscript. Essays on the Postscript to the Concept of Law, Oxford, Great Britain, Oxford University Press, 2001.

TAEKEMA, Sanne, The Concept of Ideals in Legal Theory, The Hague, The Netherlands, Kluwer Law International, 2003.

—_, "Beyond Common Sense: Philosophical Pragmatism's Relevance to Law”, Retfaerd - Nordisk Juridisk tidsskrift 29/nr. 4, 2006.

TAMANAHA, Brian Z., A General Jurisprudence of Law and Society, Oxford, Great Britain, Oxford University Press, 2001.

TwINING, William, "A Post-Westphalian Conception of Law", Law and Society Review 37, 2003. 